\section{MILITARY SPENDING AND ARMS IMPORTS BY IRAN, SAUDI ARABIA, QATAR AND THE UAE}

\author{
PIETER D. WEZEMAN AND ALEXANDRA KUIMOVA
}

\section{INTRODUCTION}

Tense relations between Iran, Qatar, Saudi Arabia and the United Arab Emirates (UAE) are a major cause for concern regarding stability, security and peace in the Gulf region and in the Middle East more generally. ${ }^{1}$ These states seek to play a major role in the Middle East and use arms as a key tool in the pursuit of this aim. Saudi Arabia and the UAE have deployed their armed forces in Yemen against Iran-backed Houthi rebels and in Syria against the Islamic State. Qatar and the UAE have been involved militarily in the conflict in Libya. Iran has sent military forces to support the Iraqi and Syrian governments. Some anti-government rebel groups in Syria have been supported by Qatar, Saudi Arabia and the UAE. In addition, all four states have provided arms to non-state armed groups in various parts of the Middle East and North Africa. These military deployments take place amid long-standing rivalries and tensions between Saudi Arabia and the UAE, on the one hand, and Iran, on the other. Moreover, in 2017 a dispute arose in which Saudi Arabia and the UAE cut all ties with Qatar and imposed sanctions.

To illustrate the importance given to military capability in these four states, this fact sheet provides a concise overview of trends and patterns of military expenditure and of arms imports-the main source of modern major arms for these states-in the period 1994-2018. ${ }^{2}$ It sketches a pattern of rapid military build-ups in Saudi Arabia, Qatar and the UAE over the past 15 years, high levels of military spending as a share of gross domestic product (GDP) in all four countries, and growing military asymmetry in which Saudi Arabia and the UAE continue to build diverse and advanced military capabilities while Iran is unable to do the same. This raises concerns about the potential effects of these developments on the volatile security situation in the Middle East, the military intentions of these four states and the role of the countries that supply them with arms. The fact sheet also highlights the absence of

\footnotetext{
${ }^{1}$ For an overview of the conflicts in the Middle East and North Africa in which these four states are involved and the related interstate rivalries see Davis, I., 'Armed conflict in the Middle East and North Africa', SIPRI Yearbook 2018: Armaments, Disarmament and International Security (Oxford University Press: Oxford, 2018), pp. 66-82.

2 This fact sheet brings together data from the SIPRI Military Expenditure Database and the SIPRI Arms Transfers Database. They provide further detail on military expenditure and arms imports in the Gulf region and the wider Middle East, as well as full information on the methodologies used.
}

\section{KEY FACTS}

- Available data indicates that Iran, Qatar, Saudi Arabia and the United Arab Emirates (UAE) had high levels of military expenditure as a share of gross domestic product (GDP) in 1994-2018.

- With a total of $\$ 67.6$ billion, Saudi Arabia was the thirdlargest military spender in the world in 2018. Iran spent $\$ 13.2$ billion on its military in 2018.

- Saudi Arabia and the UAE have built diverse and advanced military capabilities by importing arms, mainly from the United States and countries in Western Europe. Saudi Arabia was the world's largest arms importer in 2014-18. Iran's arms imports have been at a much lower level. Qatar has rapidly increased its arms imports since 2009.

- There is no government transparency on military spending in Qatar and the UAE, while questions remain about the exact military expenditure of Iran and Saudi Arabia. 


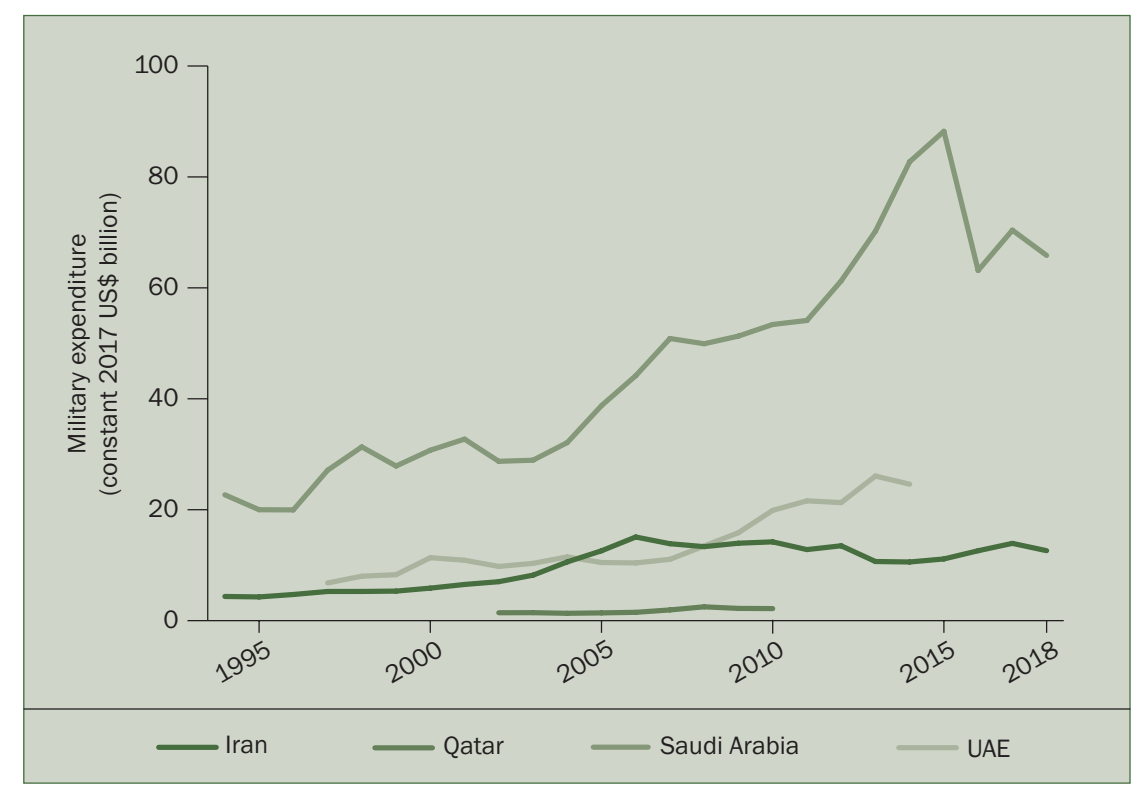

Figure 1. Military expenditure by Iran, Saudi Arabia, Qatar and the UAE, 1994-2018

Note: Data is unavailable for the UAE for 1994-96 and 2015-18, and Qatar for 1994-2001 and 2011-18.

Source: SIPRI Military Expenditure Database, Apr. 2019.

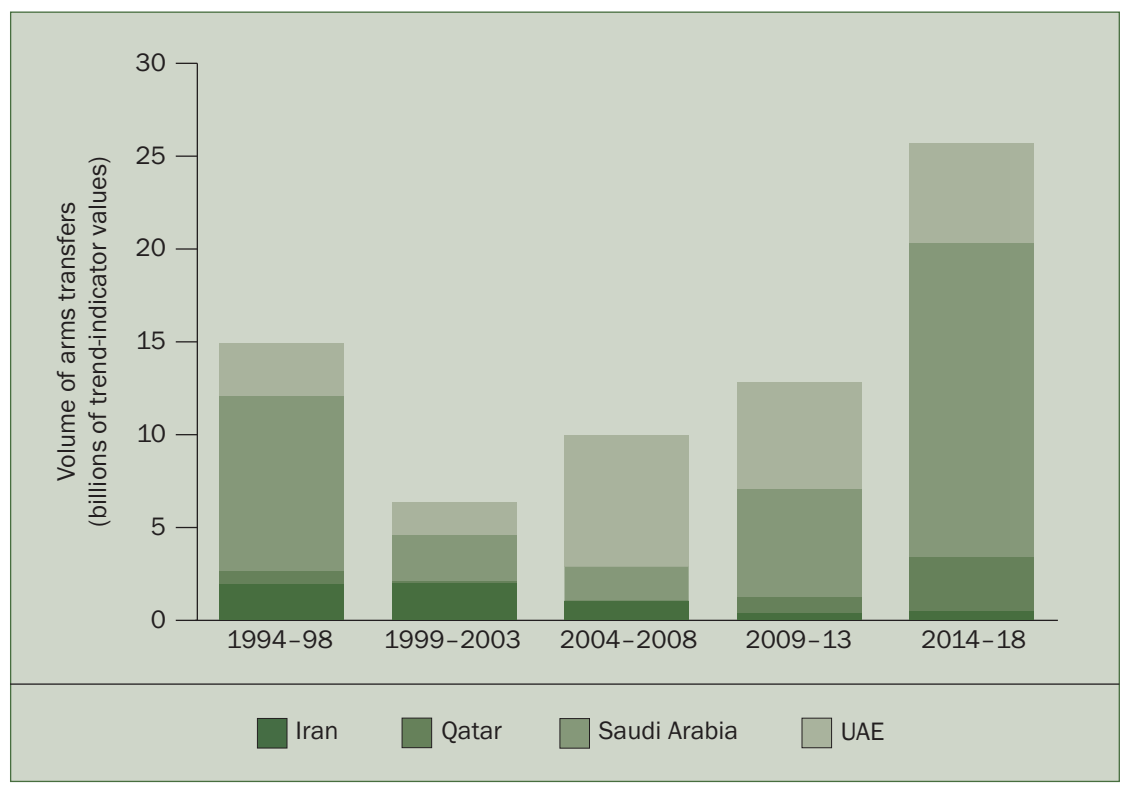

Figure 2. Major arms imports by Iran, Saudi Arabia, Qatar and the UAE, 1994-2018

Source: SIPRI Arms Transfers Database, Mar. 2019.

government transparency in military matters in these countries by discussing the lack of detailed official data on military expenditure.

\section{IRAN}

Iran's military spending in the period 1994-2018 peaked in 2006, after which it fell by 30 per cent between 2006 and 2014 (see figure 1). The fall was steepest in 2012-13, after the European Union imposed economic and financial sanctions on Iran. These sanctions and some of those imposed by the United States were lifted in 2015, which benefited the Iranian economy. Iran's military spending subsequently increased by 25 per cent between 2015 and 2017. However, in 2018 military spending decreased again, by 9.5 per cent, to $\$ 13.2$ billion, as the Iranian economy went into recession and inflation increased from 10 per cent in 2017 to 30 per cent in 2018. In 2018 military spending was 2.7 per cent of GDP, the 25th highest in the world.

The level of Iran's arms imports decreased significantly between 1994 and 2018 (see figures 2 and 3). The volume of Iran's arms imports in this period was relatively small compared with the volumes imported by many other states in the Middle East. For example, the total value of Iran's arms imports in 2009-18 was equivalent to just 3.5 per cent of Saudi Arabian arms imports in the same period. This can partly be explained by the limits on funding linked to Iran's economic problems. In addition, since 2010, United Nations Security Council resolutions have restricted the transfer of major arms to Iran. These restrictions are scheduled to remain in force until the end of $2020 .^{3}$ The sanctions allow exemptions on exports of certain arms. The delivery of four S-300 air defence systems by Russia in 2016 was Iran's first significant import of major arms since 2007. Whereas other states in the Gulf region procure arms from

\footnotetext{
${ }^{3}$ See the SIPRI arms embargoes database.
} 
a wide variety of states, 96 per cent of Iran's imports in 2014-18 came from Russia and the rest from China.

Iran has the capability to develop and produce certain types of major arms, including ballistic missiles, cruise missiles and unmanned aerial vehicles. This has to some extent offset the restrictions on its arms imports. However, the level of performance of these arms as well as other arms produced or upgraded by Iran has been questioned. ${ }^{4}$

\section{SAUDI ARABIA}

In 2018 Saudi Arabia's military spending amounted to an estimated $\$ 67.6$ billion. It was the third-largest military spender globally and by far the largest military spender in the Gulf region. There have been three periods in the past 25 years in which there were major increases in Saudi Arabia's military expenditure (see figure 1). Military expenditure increased by 57 per cent between 1996 and 1998, by 76 per cent between 2003 and 2007 and by 63 per cent between 2011 and 2015. The fall in oil prices at the end of 2014 caused a decline in government revenues, which are highly dependent on oil exports. Military spending fell by 28 per cent in 2016. ${ }^{5}$ There was then an increase of

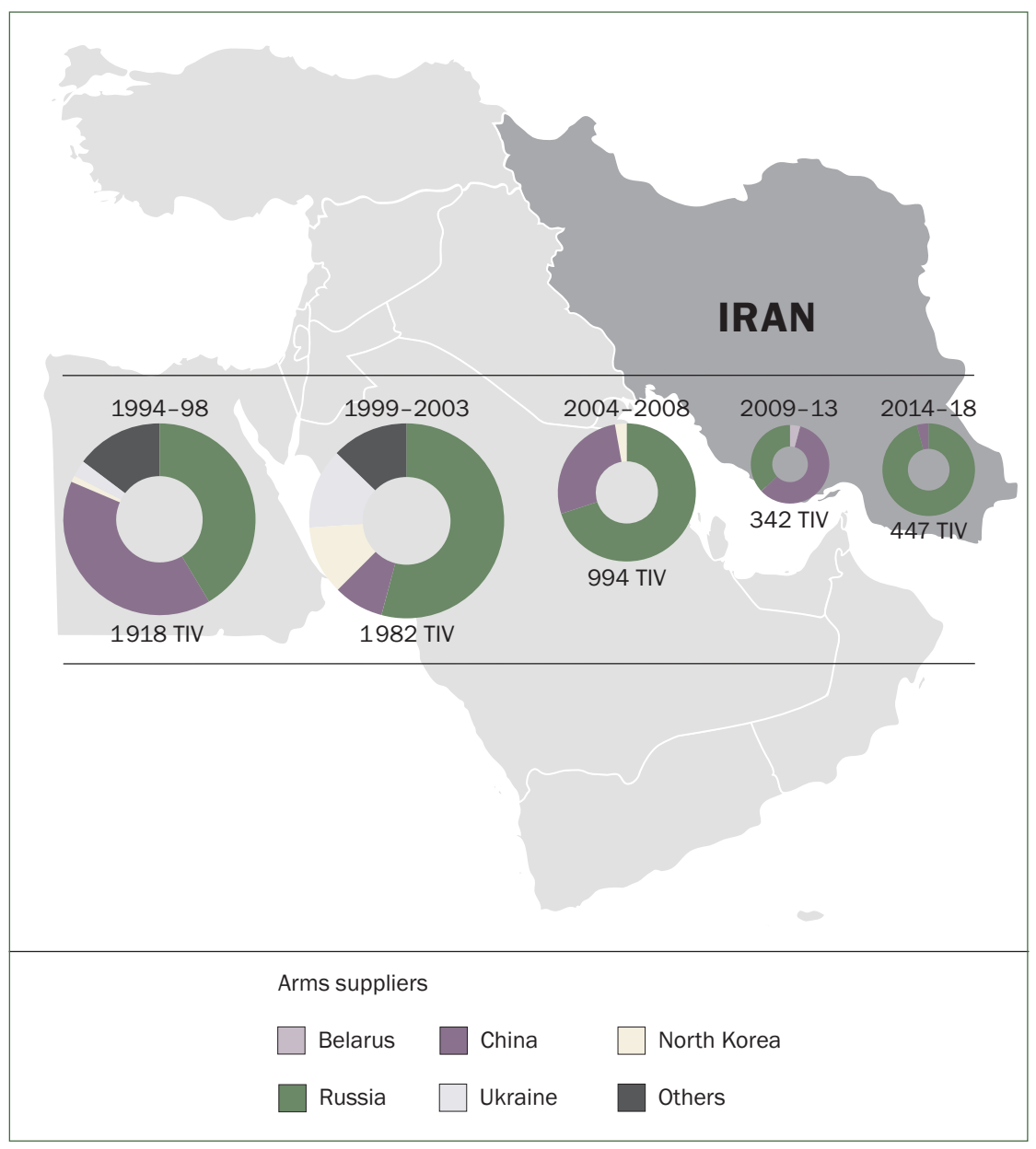

Figure 3. Imports of major arms by Iran, 1994-2018

$\mathrm{TIV}=$ millions of SIPRI trend-indicator values.

Note: Where applicable, up to the four largest suppliers in each period are named. Further information on the countries categorized as 'Others' in each period is available from the SIPRI Arms Transfers Database.

Source: SIPRI Arms Transfers Database, Mar. 2019. 11 per cent in 2017 followed by another drop, of 6.5 per cent, in 2018.

A clear indication of the high priority that Saudi Arabia gives to military capability is the fact that Saudi Arabian military spending was 8.8 per cent of GDP in 2018. At its peak in 2015, military spending was 13 per cent of GDP. In contrast, all other countries among the 15 largest military spenders in the world allocated less than 4 per cent of GDP to the military in 2018. At $\$ 2014$, Saudi Arabia's per capita military spending in 2018 was higher than any other country in the world.

After a low point in 1999-2008, arms imports increased rapidly (see figure 4). They rose by 192 per cent between 2009-13 and 2014-18, making Saudi Arabia the world's largest arms importer in 2014-18. The USA and

\footnotetext{
${ }^{4}$ Binnie, J., 'Proving grounds: assessing Iranian weapon performance in Syria and Yemen', Jane's Defence Weekly, 1 Aug. 2018, pp. 22-27; and Reuters, 'Iran starts producing local fighter jet for its air force', 2 Nov. 2018.

${ }^{5}$ For a discussion on the link between the price of oil and military expenditure see Tian, N. and Lopes da Silva, D., 'Debt, oil price and military expenditure', SIPRI Yearbook2018 (note 1), pp.171-78.
} 


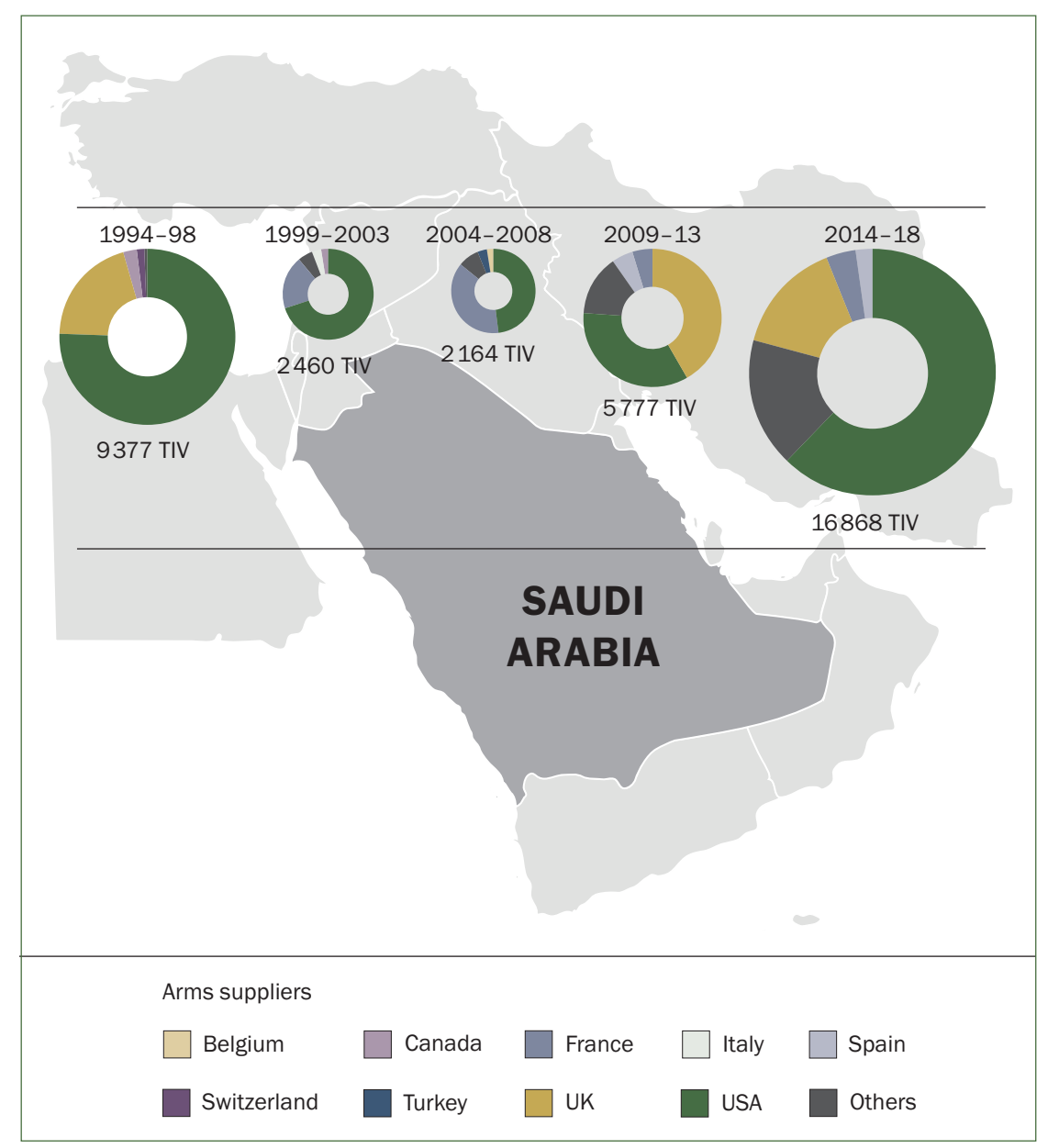

Figure 4. Imports of major arms by Saudi Arabia, 1994-2018

TIV = millions of SIPRI trend-indicator values.

Note: Where applicable, up to the four largest suppliers in each period are named. Further information on the countries categorized as 'Others' in each period is available from the SIPRI Arms Transfers Database.

Source: SIPRI Arms Transfers Database, Mar. 2019. the United Kingdom were by far the largest arms suppliers to Saudi Arabia in 2014-18 (see figure 4). A number of countries in Europe, most notably Germany, have been critical of Saudi Arabia's use of military force in Yemen and therefore restricted their arms exports to Saudi Arabia in 2018. ${ }^{6}$ However, this is likely to have little effect on Saudi Arabia's access to arms as the main, long-standing arms suppliers to Saudi Arabia-the USA, the UK and Francehave continued to supply arms. In addition, China and Russia have made significant efforts to sell arms to Saudi Arabia in recent years. ${ }^{7}$

Saudi Arabia's substantial investment in its military means that it has the largest inventory of advanced weapons among the states in the Gulf region. Imports included arms such as combat and tanker aircraft, which have increased the reach and strike power of the Saudi Arabian Air Force. The USA commenced delivery of 154 F-15SA combat aircraft in 2016, which will add to the delivery of 72 Typhoon combat aircraft by the UK in 2009-17. Both aircraft types are equipped with cruise missiles and other guided weapons. The six tanker aircraft delivered from Spain between 2011 and 2015 increase the range of Saudi Arabia's combat aircraft. At the same time, Saudi Arabia is improving its capability to defend against air and missile attacks. In 2014-18 it received 23 Patriot PAC-3 air and missile defence systems from the USA. In 2018 it ordered seven highly advanced THAAD missile defence systems from the USA.

Saudi Arabia's land and naval forces have been and continue to be modernized and expanded. In the period 2014-18, a total of over 4000 armoured vehicles were delivered from Austria, Canada, France, Georgia, South Africa and Turkey, and 338 tanks were delivered from the USA. Saudi Arabia ordered three large patrol boats from France in 2015, four frigates from the USA in 2017 and five frigates from Spain in 2018.

\footnotetext{
${ }^{6}$ Wezeman, P. D., 'Saudi Arabia, armaments and conflict in the Middle East', SIPRI Backgrounder, 14 Dec. 2018; and Jacobsen, S., 'Denmark suspends Saudi weapon export approvals over Khashoggi, Yemen concerns', Reuters, 22 Nov. 2018.

${ }^{7}$ Kuimova, A., 'Russia's arms exports to the MENA region: trends and drivers', Euro-Mediterranean Study Commission (EuroMeSCo) Policy Brief no. 95 (1 Apr. 2019).
} 
In a change from past practice, several of the current major arms import projects involve final assembly of imported arms in Saudi Arabia. For example, 68 of the F-15SA combat aircraft procured from the USA will be assembled in Saudi Arabia.

\section{QATAR}

Military expenditure by Qatar cannot be estimated for the years after 2010, when its military expenditure was $\$ 1.9$ billion (current US dollars) or 1.5 per cent of GDP (see figure 1). Between 2002 and 2010, the years for which data is available, Qatari military spending was much lower in absolute terms and as a share of GDP than such spending in the other three countries discussed.

However, in around 2010 Qatar's foreign policy and the role of its military dramatically altered. Qatar became actively involved in the conflicts in Libya and Syria and started to reshape its armed forces completely, which had until then been quite small. Although Qatar's current level of military spending is not known, public data showing a rise in the number and size of arms contracts with foreign suppliers suggests that there has been a large increase in

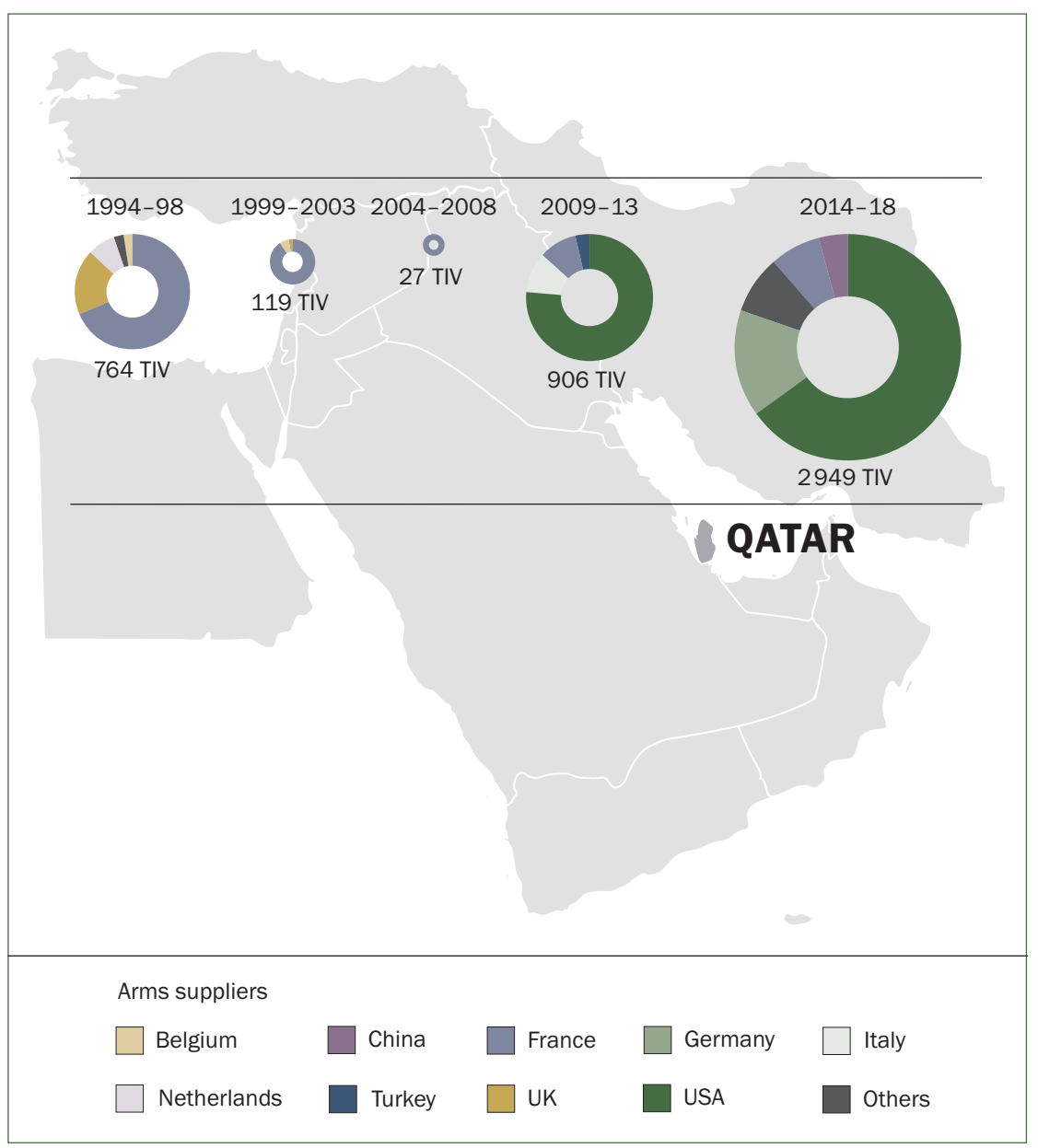

Figure 5. Imports of major arms by Qatar, 1994-2018

TIV = millions of SIPRI trend-indicator values.

Note: Where applicable, up to the four largest suppliers in each period are named. Further information on the countries categorized as 'Others' in each period is available from the SIPRI Arms Transfers Database.

Source: SIPRI Arms Transfers Database, Mar. 2019. Qatari military expenditure over the past five years. The total value of the contracts signed in the decade 2001-10 is estimated to be at least $\$ 1.5$ billion but the value of the contracts signed in 2014-18 was at least $\$ 50$ billion. ${ }^{8}$ However, actual payment schedules, which can be spread over many years, and other spending by the Qatari military, such as on salaries, training linked to the new equipment and the costs of operations, are not known.

Between 2009-13 and 2014-18, the volume of Qatar's arms imports increased by 225 per cent (see figure 5). The USA was the largest arms supplier to Qatar in 2014-18, followed by Germany. Deliveries in 2014-18 included 9 Patriot PAC-3 air and missile defence systems from the USA, 62 Leopard-2 tanks from Germany, and short-range ballistic missiles from China. In the same period, a number of contracts for even larger volumes were signed for arms for all branches of the armed forces. Among these were orders for 36 F-15QA combat aircraft from the USA, 24 Typhoon combat aircraft from

\footnotetext{
${ }^{8}$ SIPRI Arms Transfers Database (note 2).
} 


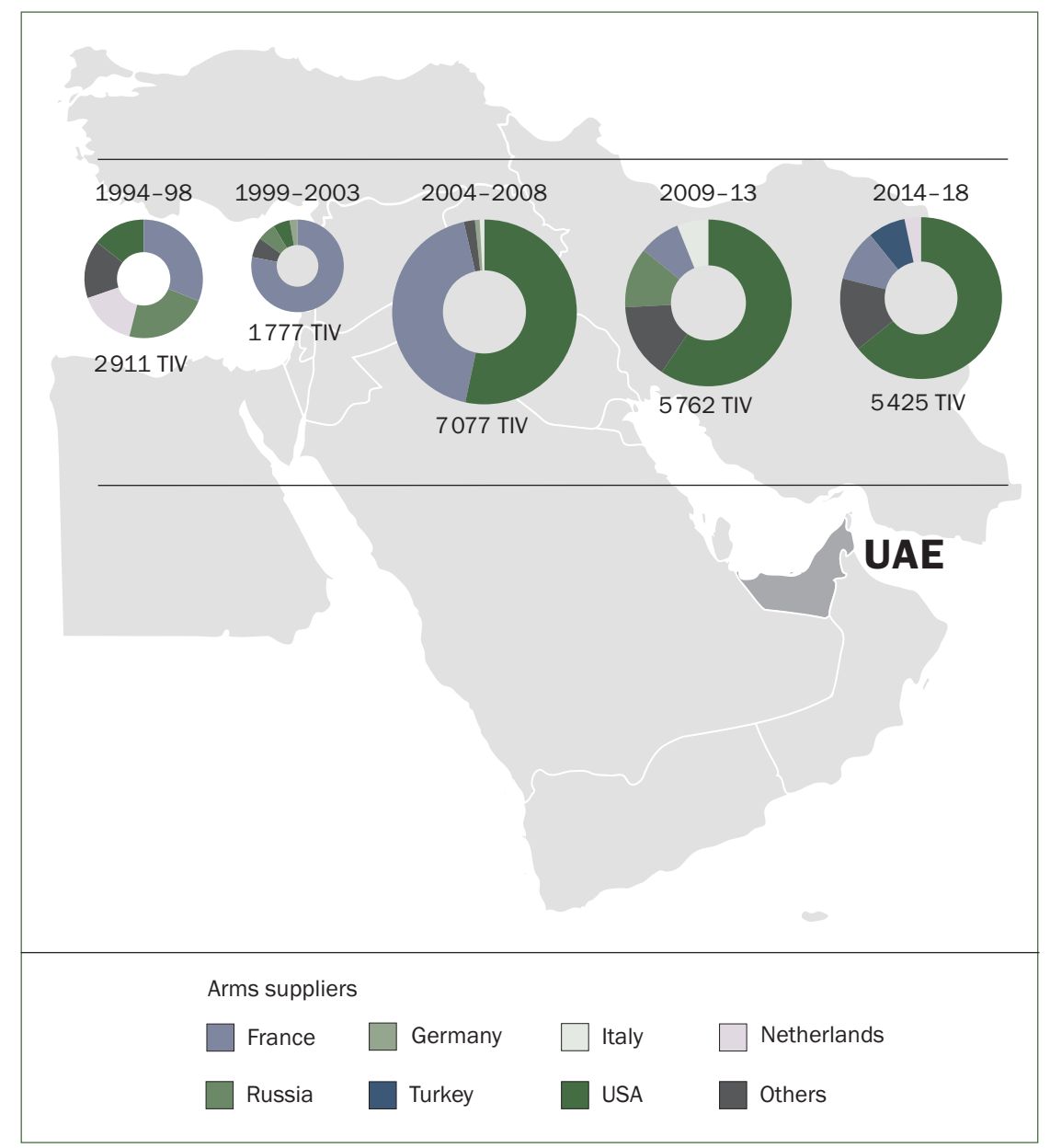

Figure 6. Imports of major arms by the UAE, 1994-2018

TIV = millions of SIPRI trend-indicator values.

Note: Where applicable, up to the four largest suppliers in each period are named. Further information on the countries categorized as 'Others' in each period is available from the SIPRI Arms Transfers Database.

Source: SIPRI Arms Transfers Database, Mar. 2019. the UK and 36 Rafale combat aircraft from France. Once these aircraft have been delivered, by around 2025, Qatar will have 96 advanced combat aircraft, equipped with cruise missiles and other guided weapons. These will replace Qatar's current fleet (as of 2018) of 12 combat aircraft. Other major procurements include 4 frigates from Italy, 490 armoured vehicles from France and 641 armoured vehicles from Turkey.

\section{THE UNITED ARAB EMIRATES}

The most recent available estimate of military spending by the UAE was $\$ 22.8$ billion (current US dollars) in 2014 (see figure 1), or 5.6 per cent of GDP. In 2014 the UAE was the secondlargest military spender in the Middle East and ranked 14th in the world. The increase in its military expenditure was particularly large between 2006 and 2014 (136 per cent).

For two reasons it is likely that the UAE's military spending in 2018 was either of the same order of magnitude or higher than in 2014. First, it was involved in major military operations in Yemen in 2018, which was not the case in 2014, and remained militarily involved in Libya, as it was in 2014. Second, it has continued to import large volumes of arms, as it did in 2014. The UAE has invested heavily in new arms since 2000. The volume of its arms imports was almost four times larger in 2004-2008 than in 1999-2003 (see figure 6). This was followed by decreases in the volume of arms imports in 2009-13 and in 2014-18. However, the UAE was still the fifth-largest arms importer worldwide in the period 2009-18. After enlarging and modernizing its fleet of combat aircraft in 2003-2008, in 2009-18 the UAE procured equipment that enhanced the reach of its armed forces, including 3 tanker aircraft, 8 long-range transport aircraft and 10 corvettes. It also acquired an advanced air and missile defence capability, comprising nine Patriot PAC-3 systems and two THAAD systems from the USA. It is currently expanding its intelligence, reconnaissance and target-acquisition capabilities, most notably with the procurement of five airborne radar systems and two surveillance satellites for delivery from 2019. The largest suppliers to the UAE in 2014-18 were the USA and France (see figure 6). 
The UAE has invested in its arms industry in the past two decades, which for example assembles armoured vehicles and missiles from South Africa and corvettes from France.

\section{MILITARY EXPENDITURE TRANSPARENCY}

SIPRI military expenditure data reflects the official data reported by national governments in official publications such as budget documents and reporting to international organizations. However, government transparency in military spending in Qatar and the UAE is almost non-existent and in Saudi Arabia is very limited. There are also doubts about the reliability of government reporting on military spending by Iran. The lack of military expenditure data is a symptom of the general lack of transparency and accountability on military matters in the Middle East.

\section{Iran}

Within the Gulf region, Iran is the most transparent in its public reporting on military expenditure. The most comprehensive document is published annually in December by the Iranian Government. It sets out the proposed government budget for the coming year, the budget adopted for the ongoing year and actual spending in previous years. The document has separate lines for each component of the regular armed forces, the Armed Forces Social Security Organization and the Iranian Revolutionary Guards Council (IRGC). Nonetheless, there are questions about whether the public document shows all the relevant spending according to the SIPRI definition of military expenditure. For example, Iran reportedly provides military aid to the Syrian Government. ${ }^{9}$ However, it is not clear in which budget line this support is included, or if it is included at all. There is also speculation that the IRGC has access to funding that is not reported in the public government documents. This would involve part of the surpluses or profits of companies controlled by the IRGC being used to fund the military activities of the IRGC. ${ }^{10}$ However, the size of these businesses and their revenues, profits or surpluses are unknown. ${ }^{11}$ The significance of IRGC business activities for Iranian military spending is therefore unclear.

\section{Saudi Arabia}

The Saudi Arabian Ministry of Finance has published data on the total budget and actual spending of the 'military sector' and the 'security and regional administration sector' since December 2016. However, the figure

\footnotetext{
${ }^{9}$ Daragahi, B., 'Iran wants to stay in Syria forever', Foreign Policy, 1 June 2018; and Lake, E., 'Iran spends billions to prop up Assad', Bloomberg, 15 June 2015.

${ }^{10}$ Chandler, J., 'Decoding Iran's defence spending: pitfalls and new pointers', Military Balance blog, International Institute for Strategic Studies, 13 Nov. 2018. See also the section on 'Military commercial activities' in 'Middle East and North Africa', International Institute for Strategic Studies, The Military Balance 2014 (Routledge: Abingdon, 2014), p. 306.

${ }^{11}$ Bozorgmehr, N., 'Iran cracks down on Revolutionary Guards business network', Financial Times, 14 Sep. 2017; and Harris, K., 'All the Sepah's men', eds Z. Abul-Magd and E. Grawert, Businessmen in Arms: How the Military and Other Armed Groups Profit in the MENA Region (Rowman and Littlefield: Lanham, MD, 2016).
} 
SIPRI is an independent international institute dedicated to research into conflict, armaments, arms control and disarmament. Established in 1966, SIPRI provides data, analysis and recommendations, based on open sources, to policymakers, researchers, media and the interested public.

\section{GOVERNING BOARD}

Ambassador Jan Eliasson, Chair (Sweden)

Dr Dewi Fortuna Anwar (Indonesia)

Dr Vladimir Baranovsky (Russia)

Espen Barth Eide (Norway) Jean-Marie Guéhenno (France)

Dr Radha Kumar (India)

Dr Patricia Lewis (Ireland/ United Kingdom)

Dr Jessica Tuchman Mathews (United States)

\section{DIRECTOR}

Dan Smith (United Kingdom)

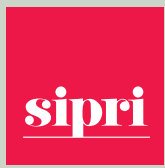

STOCKHOLM INTERNATIONAL PEACE RESEARCH INSTITUTE Signalistgatan 9 SE-169 72 Solna, Sweden Telephone: +4686559700 Email: sipri@sipri.org Internet: www.sipri.org for 'security' is not broken down. SIPRI assumes that a significant proportion of 'security' involves paramilitary forces and it therefore includes total spending on security in military spending. In the years before 2016, the only publicly available information was a single line in the government budget for 'defence and security'. The figures in this budget line, however, are unlikely to be very accurate. In the period 2010-14, total actual government spending was on average 31 per cent higher than planned for in the budget, and in 2015 it was 13 per cent higher. ${ }^{12}$ Given that defence and security spending accounted for 30 per cent of government expenditure in these years, it is likely that the overspend involved higher-than-budgeted-for spending on the military.

\section{Qatar and the United Arab Emirates}

Qatar and the UAE do not publicly report on their military spending. Data on 'defence spending' by Qatar was reported in the Government Finance Statistics published by the International Monetary Fund (IMF) most recently for $2010 .{ }^{13}$ Data is available on the budget of the UAE Ministry of Defence (MOD). ${ }^{14}$ However, the UAE MOD has only administrative functions and its budget accounts for only a small proportion of total military spending. The military expenditure of the UAE is therefore uncertain. Until 2014, IMF reports provided figures on spending on 'Abu Dhabi Federal Services', which refers to government funding from the Emirate of Abu Dhabi that the IMF has described as mainly for military and security purposes. ${ }^{15}$ In combination with the budget for the MOD, these figures are used by SIPRI to estimate total military spending in the UAE up until 2014.

\footnotetext{
${ }^{12}$ Saudi Arabian Ministry of Finance, Statements on the national budget for 2011-15; and Saudi Arabian Ministry of Finance, 'Recent economic developments and highlights of fiscal years 1436/1437 (2015) and 1437/1438 (2016)', Press release, 28 Dec. 2015.

${ }^{13}$ International Monetary Fund (IMF), Government Finance Statistics Yearbook, 2011 (IMF: Washington, DC, 2012), p. 389.

${ }^{14}$ Saleh, Y., 'UAE raises defence spending by around $41 \%$ in 2019 federal budget', Zawya, 2 Oct. 2018.

${ }^{15}$ International Monetary Fund (IMF), ‘United Arab Emirates: statistical appendix', IMF Country Report no. 07/348, Oct. 2007, p. 12.
}

\section{The SIPRI trend-indicator value}

The SIPRI trend-indicator value (TIV) is a measure of the volume of international transfers of major arms. The TIV is based on the known unit production costs of a core set of arms and is intended to represent the transfer of military resources rather than the financial value of the transfer. The method used to calculate the SIPRI TIV is described in detail on the Arms Transfers Database web page.

\section{ABOUT THE AUTHORS}

Pieter D. Wezeman (Netherlands/Sweden) is a senior researcher and Alexandra Kuimova (Russia) is a research assistant with the SIPRI Arms and Military Expenditure Programme. 